\title{
Sensitivity of groundwater recharge using climatic analogues and HYDRUS-1D
}

\author{
B. Leterme ${ }^{1}$, D. Mallants ${ }^{2}$, and D. Jacques ${ }^{1}$ \\ ${ }^{1}$ SCK-CEN, Performance Assessments Unit, Boeretang 200, Mol, Belgium \\ ${ }^{2}$ CSIRO Land and Water, Waite Campus, Urrbrae 5064 SA, Australia \\ Correspondence to: B. Leterme (bleterme@sckcen.be) \\ Received: 10 January 2012 - Published in Hydrol. Earth Syst. Sci. Discuss.: 30 January 2012 \\ Revised: 5 July 2012 - Accepted: 10 July 2012 - Published: 6 August 2012
}

\begin{abstract}
The sensitivity of groundwater recharge to different climate conditions was simulated using the approach of climatic analogue stations, i.e. stations presently experiencing climatic conditions corresponding to a possible future climate state. The study was conducted in the context of a safety assessment of a future near-surface disposal facility for low and intermediate level short-lived radioactive waste in Belgium; this includes estimation of groundwater recharge for the next millennia. Groundwater recharge was simulated using the Richards based soil water balance model HYDRUS1D and meteorological time series from analogue stations. This study used four analogue stations for a warmer subtropical climate with changes of average annual precipitation and potential evapotranspiration from $-42 \%$ to $+5 \%$ and from $+8 \%$ to $+82 \%$, respectively, compared to the present-day climate. Resulting water balance calculations yielded a change in groundwater recharge ranging from a decrease of $72 \%$ to an increase of $3 \%$ for the four different analogue stations. The Gijon analogue station (Northern Spain), considered as the most representative for the near future climate state in the study area, shows an increase of $3 \%$ of groundwater recharge for a $5 \%$ increase of annual precipitation. Calculations for a colder (tundra) climate showed a change in groundwater recharge ranging from a decrease of $97 \%$ to an increase of $32 \%$ for four different analogue stations, with an annual precipitation change from $-69 \%$ to $-14 \%$ compared to the present-day climate.
\end{abstract}

\section{Introduction}

In the context of disposal of low and intermediate level shortlived radioactive waste (LILW-SL), the Belgian Agency for Radioactive Waste and Enriched Fissile Materials (ONDRAF/NIRAS) aims at developing a disposal facility in Dessel, northeast Belgium. Demonstrating safety of the repository requires investigating the short and long-term impact of the evolution of environmental conditions on the performance of the facility. In this context, it is important to characterise future groundwater recharge, because radionuclide dispersion and dilution would eventually depend on groundwater flow conditions. The time scale of interest is several millennia, considering the long half-life of some radionuclides (i.e. several thousands to tens of thousands of years) contained in LILW-SL and the anticipated lifetime (a few thousands of years) of the near-surface facility (Van Geet et al., 2012).

Future groundwater recharge depends heavily on future climate conditions. However, studies of the impact of climate change on groundwater recharge are usually restricted to time scales of several decades to hundreds of years (e.g. Goderniaux et al., 2009; van Roosmalen et al., 2009). This is because climate scenarios of such studies are often based on predictions of general climate models (GCMs) used in IPCC assessment reports (the latest of which is IPCC, 2007). These predictions extend until $2100 \mathrm{AD}$ or $2300 \mathrm{AD}$ for some models (IPCC, 2007). Other studies do not include a specific time scale and focus more on a sensitivity analysis regarding the response of the groundwater recharge to a given change in climatic inputs (e.g. Wilkinson and Cooper, 1993). 
Different approaches have been developed to generate meteorological time series characterising different climate states in terms of average annual temperatures and precipitation:

a. Use of GCM outputs, often after downscaling of the results. Dynamical downscaling uses a regional climate model (RCM) to create higher resolution time series; while statistical downscaling includes methods of varying complexity, from (delta) perturbation approach to stochastic weather generators conditioned on sitespecific or hypothetical weather statistics (Fowler et al., 2007; Holman et al., 2009).

b. Use of actual meteorological data from instrumental analogue stations taking account of local conditions that influence hydroclimatological conditions such as similarities and differences in latitude/longitude effects on insolation and oceanic/continental influences (Palutikof and Goodess, 1991).

Using analogue stations represents a straightforward and transparent way of deriving climate state bounds for the climate classes of interest. It also has some weaknesses: analogues are restricted to sites with instrumental data; time series of 30 or $50 \mathrm{yr}$ are assumed to be representative of the long-term temporal variability of a given climate state; finally, the site conditions of analogue stations that impact their climate will hardly ever be identical to those of the site (here Dessel) they are an analogue for.

The approach based on GCMs can make use of more sitespecific information and probably provides a better paramerisation of temperature and precipitation in the near future. However, on a longer time scale as in the present study, the potential advantages of GCMs over an analogue approach are fading due to the high uncertainty in emission scenarios and GCM predictions.

The approach using analogue stations was chosen for the present study in order to describe future climate states at the Dessel site with current observations from appropriate climate zones. This approach was previously used in several safety assessment studies (Palutikof and Goodess, 1991; Bechtel SAIC Company, 2004). More recently, Stoll et al. (2011) studied groundwater recharge and quality using past analogue time series.

The objective of the present study is to estimate future groundwater recharge in the vicinity of the Dessel site on a time scale of up to a few thousands years. An estimate of current groundwater recharge is provided and the potential impact of a warmer climate is investigated using climatic analogue stations. Because of the long time scales (Van Geet et al., 2012), colder climates cannot be excluded and their impact on recharge is equally assessed. Special attention is paid to the influence of the lower boundary condition and groundwater depth.

\section{Material and methods}

\subsection{Present-day and future climate in Belgium}

The present-day climate of Belgium is defined as a temperate oceanic climate - "DO" following the classification of Trewartha et al. (1968). Classification as DO climate type requires 4 to 7 months above $10^{\circ} \mathrm{C}$ and the coldest month above $0^{\circ} \mathrm{C}$ (there is no criterion about precipitation). Climate data collected for the period 1985-2009 in the Dessel area (Campine Region, north of Belgium) indicate a mean temperature of $10.4^{\circ} \mathrm{C}$ and mean precipitation of $899 \mathrm{~mm} \mathrm{yr}^{-1}$. The atmospheric circulation is dominated by western winds which bring humidity from the Atlantic Ocean. Based on different scenarios of greenhouse gas emissions, IPCC models for the region of northern Europe predict a warming of 2.3 to $5.3^{\circ} \mathrm{C}$ (median $3.2^{\circ} \mathrm{C}$ ) by $2100 \mathrm{AD}$. Annual precipitation is very likely to increase in most of Northern Europe, and extremes of daily precipitation are also likely to increase (IPCC, 2007).

On the longer term, important driving forces of climate evolution include variations of insolation (astronomical and solar forcings), and changes in greenhouse gas and aerosol concentrations in the atmosphere (natural and anthropogenic sources). These variations are forced by changes in the Earth's orbit and spin and by other forcing agents such as volcanism, the evolution of life and the movement of tectonic plates and ocean currents. The BIOCLIM (2003) project studied possible future climate states for the long term accounting for atmospheric $\mathrm{CO}_{2}$, solar and astronomical forcings. The reference sequence of climate states (B4) is subtropical Cs/Cr climate until $160000 \mathrm{yr}$ after present (AP), followed by a temperate oceanic climate (DO from 160000 to $170000 \mathrm{yr}$ AP), then a cold climate without permafrost (EO from $170000-180000 \mathrm{yr} \mathrm{AP}$ ) and finally again a temperate climate (till $200000 \mathrm{yr}$ AP). Over the period of $10000 \mathrm{yr}$ AP chosen for the present study, BIOCLIM results suggest that northeastern Belgium will be characterised by a climate moderately warmer than present, with a similar degree of water availability through the year, but with drier summers and wetter winters ("Cs" climate in Trewartha's classification subtropical climate with winter rain). The subtropical climate class without rainfall seasonality is denoted as "Cr". No colder climate is foreseen in the next $10000 \mathrm{yr}$ AP on the basis of BIOCLIM (2003) scenarios. However for illustrative purposes the present study also investigates the consequences of a tundra climate (with permafrost) designated by "FT" in Trewartha's classification to have a more comprehensive evaluation of the water balance sensitivity at the Dessel site. 


\subsection{Climatic analogue stations}

Climate analogue stations were selected based on the following criteria: (i) fulfilling Trewartha's classification criteria based on temperature and precipitation, (ii) sufficiently long time series (preferably $>20 \mathrm{yr}$ ) of key meteorological variables (temperature, precipitation, wind speed, relative humidity) and (iii) similarity with respect to latitude/longitude effects on insolation and oceanic/continental influences compared to the Dessel site. Pertinent criteria for the latter were defined as follows:

a. Elevation: the analogue stations must have an elevation of less than $150 \mathrm{~m}$ a.s.l. This criterion is chosen to avoid the inclusion of stations displaying too important orographic rainfall effects, as the Dessel site is at approximately $25 \mathrm{~m}$ a.s.1.

b. Maritime influence: the distance to the nearest source of moisture (shoreline) has to be maximum $120 \mathrm{~km}$ taking dominant wind direction into account (Dessel site is about $120 \mathrm{~km}$ from the coast).

c. Atmospheric circulation system: analogue stations located in the Atlantic circulation system (Northern Hemisphere) are preferred. Besides, analogue stations should not be located on a small island (as in Burgess et al., 2002).

Among the potential weather stations in a given climate class $(\mathrm{Cs} / \mathrm{Cr}$, FT), the two stations displaying the smallest rank deviation from the class annual average temperature and precipitation were selected for model simulation. Besides these two stations, the two stations with the highest and lowest precipitation regimes were also selected to represent extreme (bounding) cases. This allowed assessing the influence of variability in precipitation, temperature and other climatic parameters within a climate class on groundwater recharge. Table 1 lists the selected climatic analogue stations for simulating the warmer $(\mathrm{Cs} / \mathrm{Cr})$ and colder (FT) climate classes. Table A1 (in Appendix A) presents average temperature and precipitation for twelve analogue stations of the DO climate class (with the same selection criteria as described above), including Dessel. Dessel is found to have higher annual precipitation than the class average based on these twelve stations $\left(851 \mathrm{~mm} \mathrm{yr}^{-1}\right)$, and temperature equal to the average $\left(10.3{ }^{\circ} \mathrm{C}\right)$.

\subsection{Groundwater recharge modelling}

Time series of meteorological observations were used to derive daily potential evapotranspiration (ET) using the Penman-Monteith approach (Allen et al., 1998). Site location data (altitude and latitude) of Dessel were used for all analogue stations. The altitude above sea level determines the local average value of atmospheric pressure. The latter defines the psychrometric constant which in turn is used to calculate the actual vapour pressure. The latitude defines the extraterrestrial radiation. In the adopted approach, solar radiation for all analogue stations was approximated by Hargreaves' radiation formula, using the difference between the maximum and minimum air temperatures of the analogue stations (Allen et al., 1998). Then, interception, throughfall, evaporation of intercepted water, potential evaporation and potential transpiration were calculated in a canopy water balance model implemented in Excel (see Appendix B) and were used later as input variables for HYDRUS-1D (Šimunek et al., 2005). The main outputs calculated with HYDRUS1D include daily values of the soil actual evaporation, actual transpiration and groundwater recharge (discharge at the profile bottom). From these daily values, annual values were calculated. Simulated piezometric level is assumed to be at the depth where the pressure head $(h)$ is $0 \mathrm{~cm}$. When $h<0 \mathrm{~cm}$ at the bottom of the profile, the depth of $h=0 \mathrm{~cm}$ is extrapolated assuming a unit gradient condition, i.e. $1: 1$ gradient between $h$ and $z$ (depth below ground in $\mathrm{cm}$ ). The assumption of a $1: 1$ gradient between $h$ and $z$ has been verified to be valid for our simulations.

Simulations were performed on sandy soils (podzols) characteristic of the study area, with a uniform grass cover. Three-meter deep soil profiles of Zcg (Belgian classification for sand, moderately drained, B horizon with obvious accumulation of organic matter and/or iron; FAO: Haplic Podzol, USDA: Aquic Haplorthod) and Zeg (sand, poorly drained, B horizon with obvious accumulation of organic matter and/or iron; FAO: Gleyic Podzol, USDA: Typic Haplaquod) soil series were used (Seuntjens et al., 2001). The most typical horizon sequence of these series and related texture and organic matter content properties were extracted from the Aardewerk soil information system (Van Orshoven et al., 1988). Grass rooting depth was arbitrarily set at $30 \mathrm{~cm}$. Table 2 gives the parameterisation of the two soil profiles for the van Genuchten-Mualem model (van Genuchten, 1980). The pedotransfer functions of Schaap et al. (1999) were used to derive soil hydraulic parameters for the Zcg and Zeg profiles (respectively 6 and 5 horizons).

In the Dessel area, the actual groundwater table is around $1.5 \mathrm{~m}$ deep on average (Beerten et al., 2010). Using this average groundwater table depth as the bottom boundary condition for the calculations is relevant for current climate conditions (DO class) but would not necessarily match future groundwater table conditions under other climates. For example, simulations for some of the warmer $\mathrm{Cs} / \mathrm{Cr}$ analogue stations showed that a constant groundwater table at $1.5 \mathrm{~m}$ led to a negative annual drainage (i.e. upward flow from groundwater) under a precipitation deficit (i.e. difference between precipitation and potential ET) because groundwater then acted as a supplier for actual ET (results not shown). A consequence of the high ET demand would be a drop in groundwater level, which cannot happen with the constant head boundary condition. As an alternative, the "deep drainage" bottom boundary condition implemented in 
Table 1. Characteristics of selected analogue stations for different climate classes $(\mathrm{DO}=$ temperate oceanic, $\mathrm{Cs} / \mathrm{Cr}=\mathrm{subtropical}$ with/without rainfall seasonality, FT = tundra (with permafrost)). The Dessel site is the reference station for current climate. Cádiz is the station with the smallest rank deviation from Cs class average temperature $\left(16.8^{\circ} \mathrm{C}\right)$ and precipitation $\left(607 \mathrm{~mm} \mathrm{yr}^{-1}\right)$. Ourense and Huelva were selected as bounding cases for the precipitation. For the Cr class, sufficient input data were found only for Gijon. Sisimiut and Nuuk are the stations with the smallest rank deviations from FT class average temperature $\left(-2.0^{\circ} \mathrm{C}\right)$ and precipitation $\left(571 \mathrm{~mm} \mathrm{yr}^{-1}\right)$. Paamiut and Ilulissat were selected as bounding cases for the precipitation.

\begin{tabular}{|c|c|c|c|c|c|c|}
\hline $\begin{array}{l}\text { Climate } \\
\text { class }\end{array}$ & Station & Latitude and longitude & $\begin{array}{r}\text { Mean annual } \\
\text { temperature } \\
\left({ }^{\circ} \mathrm{C}\right)\end{array}$ & $\begin{array}{r}\text { Mean annual } \\
\text { precipitation } \\
\quad\left(\mathrm{mm} \mathrm{yr}^{-1}\right)\end{array}$ & $\begin{array}{l}\text { Altitude } \\
\text { (ma.s.1.) }\end{array}$ & $\begin{array}{r}\text { Distance }(\mathrm{km}) \text { from } \\
\text { humidity source } \\
\text { (shoreline) }\end{array}$ \\
\hline DO & Dessel, Belgium & $51^{\circ} 13^{\prime} \mathrm{N}, 05^{\circ} 06^{\prime} \mathrm{E}$ & 10.3 & 899 & 20 & 120 \\
\hline Cs & Ourense, Spain & $42^{\circ} 20^{\prime} \mathrm{N}, 07^{\circ} 52^{\prime} \mathrm{W}$ & 14.5 & 807 & 143 & 90 \\
\hline $\mathrm{Cs}$ & Cádiz, Spain & $36^{\circ} 45^{\prime} \mathrm{N}, 06^{\circ} 04^{\prime} \mathrm{W}$ & 17.7 & 536 & 27 & 0 \\
\hline $\mathrm{Cs}$ & Huelva, Spain & $37^{\circ} 17^{\prime} \mathrm{N}, 06^{\circ} 55^{\prime} \mathrm{W}$ & 18.1 & 479 & 19 & 0 \\
\hline $\mathrm{Cr}$ & Gijon, Spain & $43^{\circ} 32^{\prime} \mathrm{N}, 05^{\circ} 39^{\prime} \mathrm{W}$ & 13.8 & 947 & 3 & 0 \\
\hline FT & Nuuk, Greenland & $64^{\circ} 10^{\prime} \mathrm{N}, 51^{\circ} 45^{\prime} \mathrm{W}$ & -1.4 & 740 & $54 / 80$ & 0 \\
\hline FT & Ilulissat, Greenland & $69^{\circ} 13^{\prime} \mathrm{N}, 51^{\circ} 03^{\prime} \mathrm{W}$ & -5.0 & 268 & 39 & 0 \\
\hline FT & Sisimiut, Greenland & $66^{\circ} 55^{\prime} \mathrm{N}, 53^{\circ} 40^{\prime} \mathrm{W}$ & -3.9 & 319 & 12 & 0 \\
\hline FT & Paamiut, Greenland & $62^{\circ} 00^{\prime} \mathrm{N}, 49^{\circ} 43^{\prime} \mathrm{W}$ & -0.8 & 794 & 15 & 0 \\
\hline
\end{tabular}

HYDRUS-1D was used, for which the discharge rate $q(n)$ at the bottom of the soil profile at node $n$ is defined as a function of the position of the groundwater table (Hopmans and Stricker, 1989):

$q(n)=q(h)=A_{q h} \exp \left(B_{q h} \times \mid h-\right.$ GWLOL $\left.\mid\right)$

where $q(h)\left[\mathrm{cmday}^{-1}\right]$ is the discharge rate, $h[\mathrm{~cm}]$ is the pressure head at the bottom of the soil profile, $A_{q h}$ $\left[\mathrm{cm} \mathrm{day}^{-1}\right]$ and $B_{q h}\left[\mathrm{~cm}^{-1}\right]$ are empirical parameters and GWLOL $[\mathrm{cm}]$ is the reference groundwater depth. In this case vertical drainage across the lower boundary of the soil profile is approximated by a flux, which depends on the position of the groundwater level (Hopmans and Stricker, 1989). Parameters for Eq. (1) were obtained from a series of measured groundwater levels in the Dessel area (1990-2009) and corresponding calculated fluxes (Leterme et al., 2012). An average parameter $B_{q h}\left(=-0.0083 \mathrm{~cm}^{-1}\right)$ was fitted for the $12 \mathrm{se}$ lected piezometers (average annual minimum and maximum water level of these piezometers are 1.2 and $2.1 \mathrm{~m}$, respectively). $A_{q h}\left(=-0.667 \mathrm{~cm} \mathrm{day}^{-1}\right)$ was calculated following Hopmans and Stricker (1989) and GWLOL was set to $300 \mathrm{~cm}$ (= depth of the simulation domain). This variable drainage flux-water table bottom boundary condition was used for all climate states. The initial pressure head at the lower boundary of the simulation domain was set to $h=-150 \mathrm{~cm}$. Any impact of the initial pressure head distribution on simulation results was avoided by using six warm-up years.

\section{Results and discussion}

\subsection{Inter-annual variability}

Table 3 shows the long-term arithmetic average water budget related to groundwater recharge for a grass cover using analogue climatic data. In the current climate (Dessel, DO), simulated groundwater recharge is $314 \mathrm{~mm} \mathrm{yr}^{-1}$ on average (35\% of total rainfall). Actual ET $\left(\mathrm{ET}_{\mathrm{a}}\right)$ is $96 \%$ of potential ET $\left(\mathrm{ET}_{0}\right)$ and $55 \%$ of total rainfall. The simulated value of groundwater recharge ( $314 \mathrm{~mm} \mathrm{yr}^{-1}$ ) was previously compared to other studies assessing groundwater recharge for approximately the same study area (see the review in Hardy et al., 2001). Values ranged from 237 to $486 \mathrm{~mm} \mathrm{yr}^{-1}$ (28 to $60 \%$ of total rainfall). However, in the studies reviewed by Hardy et al. (2001), different techniques, different time series and different numbers for runoff were used adding to the variability. More recently, Batelaan and De Smedt (2007) combined GIS data and hydrological modelling with the WetSpass model. For the combination of meadows and sand soil texture (as in the present study), their simulations gave a groundwater recharge of about $325 \mathrm{~mm} \mathrm{yr}^{-1}$, which corresponds well with our simulation.

Simulations for the warmer climate class $(\mathrm{Cs} / \mathrm{Cr})$ show a decrease of groundwater recharge compared to the present climate station for all analogue stations except Gijon. For Huelva and Cádiz, there is a precipitation deficit $\left(\mathrm{ET}_{0} \gg P\right)$, which leaves little water available for groundwater recharge. Results show an increase of groundwater recharge for Gijon $(+3 \%)$ compared to the present climate station. The increase in both precipitation $(+5 \%)$ and $\mathrm{ET}_{0}(+8 \%)$ at Gijon compared to Dessel resulted in a higher $\mathrm{ET}_{\mathrm{a}}(+7 \%)$ and groundwater recharge. Because of the small difference in groundwater recharge, the simulated depth of the groundwater table does not change with Gijon data $(2.6 \mathrm{~m})$ compared to current Dessel data $(2.6 \mathrm{~m})$. As mentioned above, the actual groundwater table in the Dessel area is approximately $1.5 \mathrm{~m}$ deep. The difference between the simulations and field observations is partly due to the use of the "deep drainage" boundary condition which would not be optimal for the present case, 
Table 2. Parameters of the van Genuchten-Mualem model for the Zcg and Zeg soil profiles (estimated with pedotransfer function derived by Schaap et al., 1999). $\theta_{\mathrm{r}}$ and $\theta_{\mathrm{S}}$ are residual and saturated water content, respectively, $K_{\mathrm{S}}$ is saturated hydraulic conductivity, and $\alpha, n$, and $l$ are curve shape parameters.

\begin{tabular}{lllrrrrrr}
\hline $\begin{array}{l}\text { Soil } \\
\text { profile }\end{array}$ & Horizon & $\begin{array}{l}\text { Depth } \\
(\mathrm{cm})\end{array}$ & $\begin{array}{r}\theta_{\mathrm{r}} \\
\left(\mathrm{m}^{3} \mathrm{~m}^{-3}\right)\end{array}$ & $\begin{array}{r}\theta_{\mathrm{s}} \\
\left(\mathrm{m}^{3} \mathrm{~m}^{-3}\right)\end{array}$ & $\begin{array}{r}\alpha \\
\left(\mathrm{m}^{-1}\right)\end{array}$ & $\begin{array}{r}n \\
(-)\end{array}$ & $\begin{array}{r}K_{\mathrm{s}} \\
\left(\mathrm{m} \mathrm{s}^{-1}\right)\end{array}$ & $\begin{array}{r}l \\
(-)\end{array}$ \\
\hline Zcg & A1 & $0-5$ & 0.06 & 0.47 & 1.3 & 1.68 & $2.3 \times 10^{-5}$ & 0.5 \\
& A2 & $5-8$ & 0.03 & 0.40 & 1.6 & 1.75 & $2.3 \times 10^{-5}$ & 0.5 \\
& Bh & $8-10$ & 0.05 & 0.45 & 1.4 & 1.62 & $4.5 \times 10^{-6}$ & 0.5 \\
& Bi & $10-13$ & 0.03 & 0.40 & 1.6 & 1.75 & $4.5 \times 10^{-6}$ & 0.5 \\
& BC & $13-17$ & 0.02 & 0.38 & 1.5 & 1.71 & $1.3 \times 10^{-4}$ & 0.5 \\
& C & $17-300$ & 0.02 & 0.38 & 1.6 & 1.75 & $1.3 \times 10^{-4}$ & 0.5 \\
& A1 & $0-9$ & 0.06 & 0.46 & 1.3 & 1.63 & $4.7 \times 10^{-5}$ & 0.5 \\
& A2 & $9-15$ & 0.02 & 0.38 & 1.7 & 1.86 & $4.7 \times 10^{-5}$ & 0.5 \\
& Bh & $15-21$ & 0.03 & 0.41 & 1.5 & 1.68 & $6.1 \times 10^{-6}$ & 0.5 \\
& Bi & $21-43$ & 0.03 & 0.40 & 1.6 & 1.73 & $6.1 \times 10^{-6}$ & 0.5 \\
& BC & $43-300$ & 0.02 & 0.39 & 1.5 & 1.71 & $1.6 \times 10^{-5}$ & 0.5 \\
\hline
\end{tabular}

Table 3. Average annual precipitation $(P)$, potential evapotranspiration $\left(\mathrm{ET}_{0}\right)$, actual evapotranspiration $\left(\mathrm{ET}_{\mathrm{a}}\right)$, evaporation of intercepted water $\left(E_{\mathrm{i}}\right)$, soil evaporation $\left(E_{\mathrm{a}}\right)$, transpiration $\left(T_{\mathrm{a}}\right)$ and groundwater recharge, in $\mathrm{mm} \mathrm{yr}^{-1}$ for Dessel and the 8 analogue stations. In parenthesis the percentage of precipitation is given for some variables.

\begin{tabular}{lrrrrrrr}
\hline Station & $\mathrm{P}$ & $\mathrm{ET}_{0}$ & $\mathrm{ET}_{\mathrm{a}}$ & $E_{\mathrm{i}}$ & $E_{\mathrm{a}}$ & $T_{\mathrm{a}}$ & Recharge \\
\hline Dessel (DO) & 899 & 596 & 572 & $81(9 \%)$ & $206(23 \%)$ & $285(32 \%)$ & $314(35 \%)$ \\
Huelva (Cs) & 518 & 1088 & 430 & $29(6 \%)$ & $113(22 \%)$ & $288(56 \%)$ & $89(17 \%)$ \\
Cádiz (Cs) & 524 & 910 & 437 & $31(6 \%)$ & $111(21 \%)$ & $295(56 \%)$ & $87(17 \%)$ \\
Ourense (Cs) & 863 & 784 & 602 & $56(6 \%)$ & $181(21 \%)$ & $365(42 \%)$ & $216(25 \%)$ \\
Gijon (Cr) & 947 & 646 & 617 & $70(7 \%)$ & $217(23 \%)$ & $325(34 \%)$ & $322(34 \%)$ \\
Ilulissat (FT) & 282 & 417 & 264 & $46(16 \%)$ & $88(31 \%)$ & $130(46 \%)$ & $9(3 \%)$ \\
Sisimiut (FT)* & 306 & 375 & 272 & $42(14 \%)$ & $89(29 \%)$ & $140(46 \%)$ & $47(15 \%)$ \\
Nuuk (FT) & 747 & 407 & 405 & $69(9 \%)$ & $149(20 \%)$ & $187(25 \%)$ & $328(44 \%)$ \\
Paamiut (FT) & 774 & 376 & 370 & $58(7 \%)$ & $133(17 \%)$ & $179(23 \%)$ & $415(54 \%)$ \\
\hline
\end{tabular}

* The sum of $\mathrm{ET}_{\mathrm{a}}$ and recharge is higher than $P$. This is due to a strong decrease of soil water content (about $-400 \mathrm{~mm}$ per unit area in the 3-m soil profile) between the start (wetter) and end (drier) of the 24-yr simulation period, resulting in a recharge increase.

but other factors affecting groundwater table depth were not accounted for (e.g. rivers, topography). Further work will address this issue, for example, by coupling the unsaturated zone model with a local hydrogeological model.

In a study using GCM and RCM downscaling, Goderniaux et al. (2009) estimated the impact of climate change by 2100 on the regional water balance in a Belgian catchment (the Geer basin $\sim 70 \mathrm{~km}$ from Dessel, chalk aquifer). They applied 6 scenarios derived from combinations of the A2 scenario run on 2 different GCMs with 4 different RCMs for downscaling. Annual mean temperature increase ranges from $+3.5^{\circ} \mathrm{C}$ to $+5.6^{\circ} \mathrm{C}$, and annual precipitation decrease from $-1.9 \%$ to $-15.3 \%$ (with increase in winter and decrease in summer). Groundwater recharge is not explicitly given in the water balance, but their simulations (coupled surface, subsurface and groundwater flow) gave the following results for the period 2071-2100 compared to the control period 1961-1990: (i) slight increase of the ratio $\mathrm{ET}_{\mathrm{a}} / P$
$(+2-4 \%)$, (ii) decrease of groundwater levels (i.e. decrease of groundwater recharge) and (iii) decrease of surface flow rates $(-9$ to $-33 \%)$.

It is important to note that groundwater table depth is in a critical interval of values where ET can be considered to be "groundwater controlled" (Maxwell and Kollet, 2008). This means that the $\mathrm{ET}_{\mathrm{a}}$ (and groundwater recharge) response to a given increase in temperature and/or precipitation strongly depends on groundwater table depth. Shallow groundwater tables $(<1 \mathrm{~m})$ would ensure a constant $\mathrm{ET}_{\mathrm{a}}$ response for any change in $\mathrm{ET}_{0}$ (i.e. surface fluxes are not water limited). Deep groundwater tables would cause precipitation and landsurface processes to be the drivers of groundwater recharge (i.e. groundwater is disconnected from surface processes; Fig. 2 in Maxwell and Kollet, 2008). The depth at which groundwater becomes disconnected from surface processes is suggested to be 7-8 $\mathrm{m}$ in Maxwell and Kollet (2008), but it 

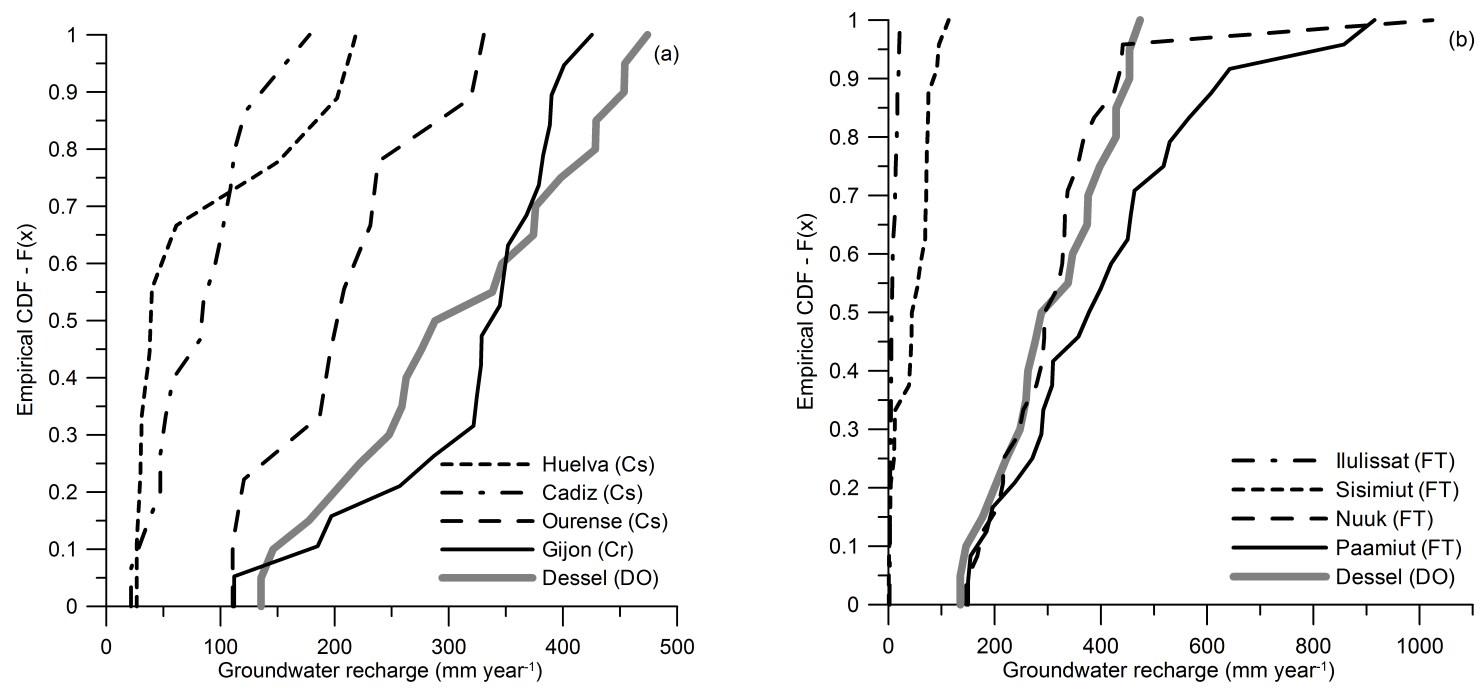

Fig. 1. Cumulative distribution functions of annual groundwater recharge simulated for (a) Cs and Cr and (b) FT analogue stations. The DO reference simulation of the Dessel site is included for comparison.

could be less for example in case of coarse textured soil and shallow rooted vegetation (e.g. Peck, 1978).

Analogue stations of the colder FT class show two contrasting types of water budget. Ilulissat and Sisimiut have a very low annual precipitation and hence very small groundwater recharge despite limited $\mathrm{ET}_{0}$ and $\mathrm{ET}_{\mathrm{a}}$ compared to present-day climate class. Nuuk and Paamiut have an annual precipitation similar to current Dessel climate, but groundwater recharge increases due to low ET. The snow hydrology module of HYDRUS-1D (snow fall and melting) was tested for the FT and DO classes (results not shown) but did not show any significant impact due to a low runoff potential (high infiltration capacity of Zcg and Zeg profiles) and to the use of daily time steps. However, soil freezing and thawing were not simulated in the present study and these would probably reduce groundwater recharge for analogue stations of the FT class. The simulations represent an upper bound of groundwater recharge (by neglecting runoff of snow melt), and the lower bound could be approximated by the difference between this upper bound and the average snowpack accumulation before spring melting (i.e. assuming all snow becomes runoff or evaporates). This gives a lower bound value of $\sim 16 \mathrm{~mm} \mathrm{yr}^{-1}$ groundwater recharge for Sisimiut, compared to $96 \mathrm{~mm} \mathrm{yr}^{-1}$ when all snow infiltrates. Getting a more precise estimation between these two bounds would require the effect of soil freezing and snow accumulation on soil water flux to be modelled. For example, frozen soil development was shown to be highly dependent on the timing of snowpack accumulation and induced ground isolation (Iwata et al., 2008).

Figure 1a depicts the cumulative distribution functions (CDFs) of annual groundwater recharge simulated for the climatic analogues of the $\mathrm{Cs} / \mathrm{Cr}$ class and comparison with the simulation for Dessel. In the upper percentiles, Gijon shows lower groundwater recharge than Dessel despite having higher precipitation (i.e. supplementary available water in wetter years is primarily used to satisfy high ET demand). The CDFs of annual recharge (Fig. 1a) show that climate variability at Dessel is a more important factor than climate change based on Gijon as representative analogue for warmer climate (see Sect. 3.2). For instance, the interquartile range of Dessel CDF is $178 \mathrm{~mm} \mathrm{yr}^{-1}$, while the difference between the medians of Dessel and Gijon annual recharges is only $32 \mathrm{~mm} \mathrm{yr}^{-1}$. Climate change based on Ourense analogue station is similar to Dessel climate variability measured by the interquartile range, while climate change based on Huelva and Cádiz analogue stations is more important than Dessel climate variability.

Figure $1 \mathrm{~b}$ depicts the cumulative distribution functions of annual groundwater recharge simulated for the climatic analogues of the FT class and comparison with the simulation for Dessel. The contrast mentioned above between Ilulissat and Sisimiut on the one hand, and Nuuk and Paamiut on the other hand, is clearly visible. The former stations have a very low annual precipitation and small groundwater recharge, while the latter show higher groundwater recharge than Dessel despite lower precipitation (Table 3). Note that calculations did not account for snow evaporation; therefore, calculated recharge may be overestimated.

\subsection{Representative analogue stations}

Although simulating groundwater recharge with several analogue stations gives a good representation of the variability within a climate class, one may choose a representative analogue among the different stations to try reducing the uncertainty on possible future groundwater recharge. Ancillary 
information on probable future climate conditions can help to assess the representativeness of the climatic analogue stations.

In the case of $\mathrm{Cs} / \mathrm{Cr}$ climate class, for example, Gijon is considered as the best representative analogue given its resemblance in temperature and precipitation characteristics with projected climate evolution in the near future at Dessel. The seasonal distribution and magnitude of temperature and precipitation increases for Gijon are consistent with GCM scenarios of IPCC (2007). Indeed, the latter projects a median annual precipitation increase for Northern Europe of $9 \%$ and a temperature increase of $3.2^{\circ} \mathrm{C}$. For Gijon, precipitation and temperature are, respectively, by $5 \%$ and $3.4{ }^{\circ} \mathrm{C}$ higher compared to Dessel. Although Gijon is classified as a subtropical climate without rainfall seasonality, summers are drier and winters are wetter than in Dessel (see Fig. 2), which is in accordance with BIOCLIM projections of future climate for the next $10000 \mathrm{yr}$ (Sect. 2.1).

Concerning the colder climate (FT class), Sisimiut is considered as the best representative analogue based on inference from geological records of the last glacial period indicating that the coldest periods were very dry in the Dessel area. This is supported in the region of the Belgian-Dutch border by evidence such as deflation horizons indicating strong wind erosion, abundant aeolian deposition, (near) absence of fluvial activity in the valleys (Vandenberghe, 1985, 1993). It is reasonable to assume that precipitation during colder periods has been much lower than today. For instance, Wemaere et al. (1999) examined future climate scenarios based on a definition of climate intervals characterised by paleo-reconstruction starting from $126000 \mathrm{yr} \mathrm{BP}$. Boreal, periglacial, and glacial climate states were found to display very low infiltration rates (at least two orders of magnitude lower compared to present-day values for moderate conditions).

\subsection{Intra-annual variability}

For the baseline station (Dessel) and two representative analogue stations (Gijon and Sisimiut), Fig. 2 shows the intraannual variability of $\mathrm{ET}_{\mathrm{a}}$ and groundwater recharge. Even though Gijon is classified as a subtropical station without rainfall seasonality, summer is somewhat drier and this is reflected in a slight decrease of $\mathrm{ET}_{\mathrm{a}}$ in the summer months compared to Dessel. Seasonality of groundwater recharge is similar between Dessel and Gijon. The bottom boundary condition (Eq. 1) prevents a net upward flux at the bottom of the profile (water supply from the aquifer), but allows the groundwater table to fluctuate. For Dessel simulations, groundwater table is $90 \%$ of the time between 1.7 and $3.6 \mathrm{~m}$ deep. For the Gijon simulations, the fluctuation interval is slightly larger (1.6 and $3.7 \mathrm{~m}$ deep).

Sisimiut is characterised by low annual precipitation and groundwater recharge shows almost no seasonality. Average groundwater depth of the numerical simulations is $6.0 \mathrm{~m}$.
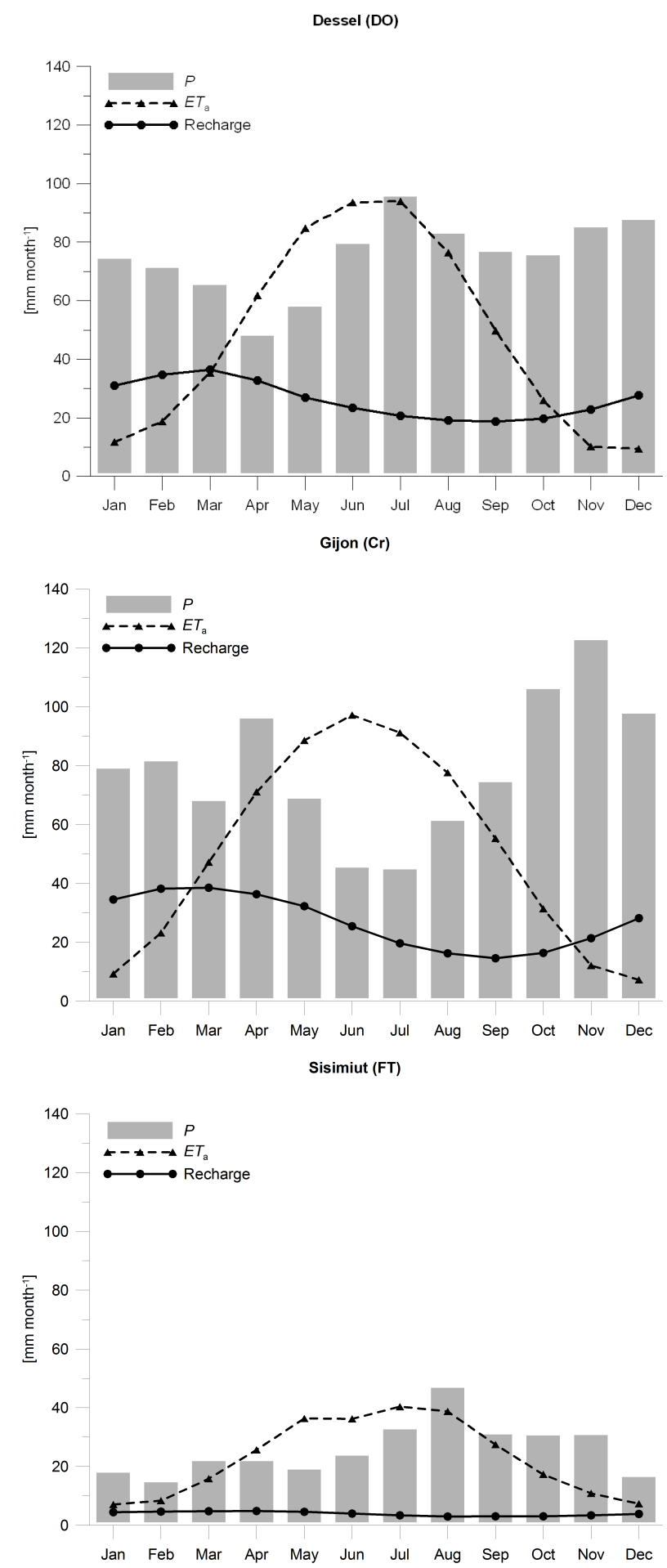

Fig. 2. Monthly average precipitation $(P)$, actual evapotranspiration $\left(E_{\mathrm{a}}\right)$ and groundwater recharge for the analogue stations of Dessel (DO, top), Gijon (Cr, middle) and Sisimiut (FT, bottom). 


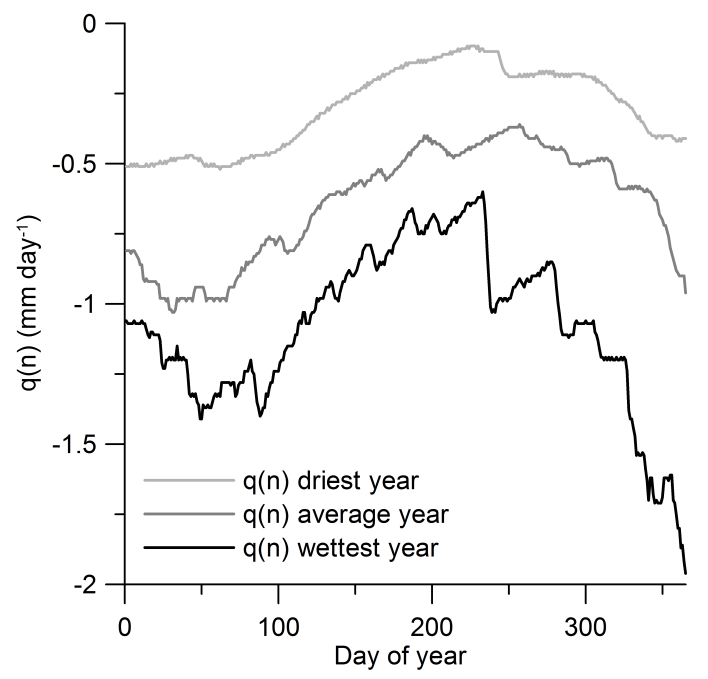

Fig. 3. Daily simulated flux $\left(q(n)\right.$ in $\left.\mathrm{mmday}^{-1}\right)$ at the bottom of the $3 \mathrm{~m} \mathrm{Zcg}$ soil profile for present-day Dessel climate. The flux is shown for the driest (light grey line) and the wettest (black line) years of the 1984-2005 series, as well as for a year close to the average annual precipitation (grey line). Negative $q(n)$ is downwards in the soil profile.

Simulated flux $q(n)$ (or groundwater recharge; Eq. 1) at the bottom of the soil profile varies between -0.1 and $-2.9 \mathrm{~mm} \mathrm{day}^{-1}$ (negative is downwards) for Dessel during the whole time series. Figure 3 shows this flux over time for a dry $\left(P=616 \mathrm{~mm} \mathrm{yr}^{-1}\right)$, an average $\left(P=927 \mathrm{~mm} \mathrm{yr}^{-1}\right)$ and a wet $\left(P=1088 \mathrm{~mm} \mathrm{yr}^{-1}\right)$ year. All three are characterized by lower flux in the summer and higher flux in the winter. It can also be seen that due to the formulation of the bottom boundary condition (Eq. 1), $q(n)$ is always negative (i.e. downwards) at the bottom of the soil profile, even in dry periods.

\subsection{Sensitivity to the deep drainage bottom boundary condition and to model structure}

In the present case, shallow water table results in capillary rise, meaning that more water is available for plant transpiration and soil evaporation. For Dessel, simulations using a free drainage bottom boundary condition (i.e. deep groundwater and capillary rise effect excluded) resulted in an average $E_{\text {a }}$ of $166 \mathrm{~mm} \mathrm{yr}^{-1}$ and $T_{\mathrm{a}}$ of $232 \mathrm{~mm} \mathrm{yr}^{-1}$ (compared to 206 and $285 \mathrm{~mm} \mathrm{yr}^{-1}$ respectively, in the case of a deep drainage boundary condition; Table 3 ). The presence of a groundwater table at $2.6 \mathrm{~m}$ depth on average for Dessel increases simulated $\mathrm{ET}_{\mathrm{a}}$ by $20 \%$ (491 compared to $398 \mathrm{~mm} \mathrm{yr}^{-1}$ ).

Figures 4 and 5 illustrate the impact of the boundary condition on soil water content, i.e. deep drainage compared to free drainage boundary condition. The water content profile in Fig. 4 clearly illustrates the effect of capillarity near the groundwater table with significantly higher water contents.

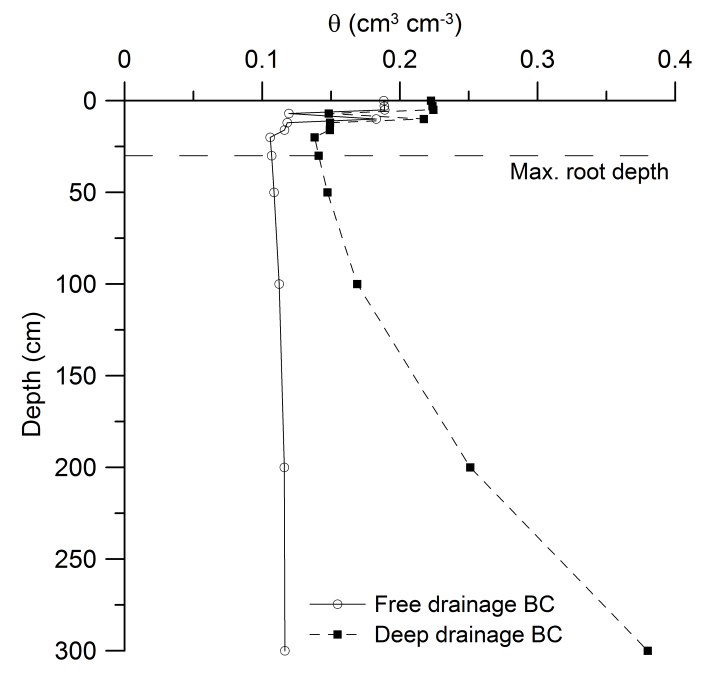

Fig. 4. Effect of bottom boundary condition (free drainage vs. deep drainage) on soil water content profile. Illustration at time $t=2192$ days of the simulation for the Zcg profile and DO Dessel climate data. In the deep drainage simulation groundwater table is $290 \mathrm{~cm}$ deep at $t=2192$ days.

However, higher water contents are persistent in almost the complete profile (up to the root zone; Fig. 4) and throughout the year (not shown). Figure 5 shows a one-year time series of water flux at $30 \mathrm{~cm}$ and $200 \mathrm{~cm}$ depth. It can be seen that between precipitation events, especially in the summer, capillary rise and groundwater uptake are important with a deep drainage boundary condition. At $30 \mathrm{~cm}$ depth, water fluxes following high rainfall are similar for both types of bottom boundary conditions. However, between high rainfall events one can clearly observe that simulated capillary rise and hence groundwater uptake is much more important in the case of a deep drainage boundary condition. At $200 \mathrm{~cm}$ depth, patterns are similar but less pronounced. For the particular year depicted in Fig. 5, simulated groundwater recharge was 179 and $284 \mathrm{~mm} \mathrm{yr}^{-1}$ with a deep drainage and a free drainage boundary condition, respectively.

Due to this higher water storage in the vadose zone by effects of capillary rise and groundwater uptake, $\mathrm{ET}_{\mathrm{a}}$ is higher in case of a relatively high groundwater table.

In the present study, the type of bottom boundary condition was identified as the most important source of variation in the simulation results, mainly due to the presence of a shallow groundwater table under current climate conditions. Different time discretization of input precipitation were also tested but had no significant influence on average annual groundwater recharge in the present study (results not shown), because of the highly permeable soil type (i.e. no runoff except in a few very extreme precipitation events). The effect of other model asumptions was beyond the scope of this study, but can be anticipated based on the literature. 


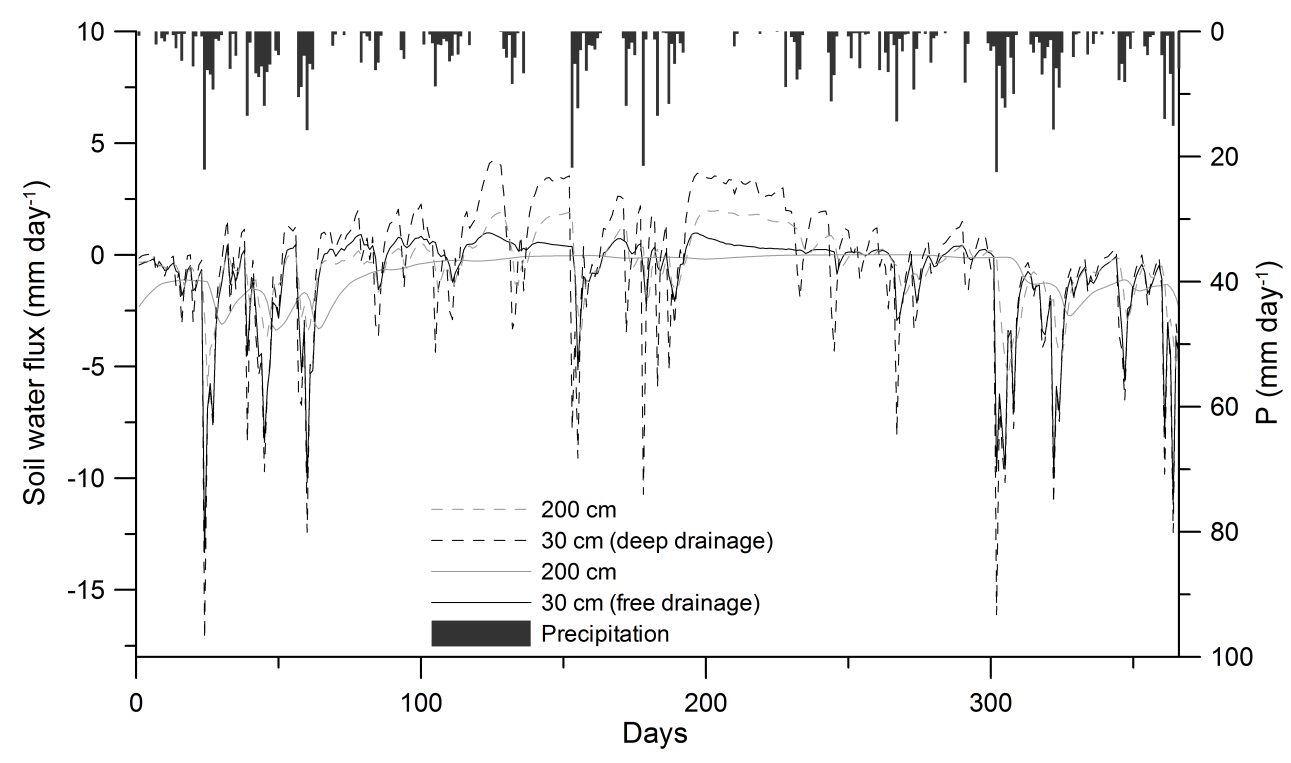

Fig. 5. One-year time series of precipitation and simulated water flux at $30 \mathrm{~cm}$ (maximum rooting depth) and $200 \mathrm{~cm}$ depth in the Zcg soil profile for the DO climate class (Dessel), showing the influence of the bottom boundary condition (solid lines: free drainage; dashed lines: deep drainage). Negative flux is downwards and positive is upwards in the soil profile.

The HYDRUS-1D model structure was previously compared to six other models by Scanlon et al. (2002). Drainage measured in a lysimeter experiment could be estimated within $\pm 64 \%$ by most codes. Scanlon et al. (2002) showed that divergences in simulation outputs could be attributed to (i) modelling concept (Richards equation vs. capacity model); (ii) upper boundary condition (ET $\mathrm{ET}_{0}$ during precipitation set to zero vs. substracted from $P$ ) and time discretization of precipitation (cf. also Mertens et al., 2002); (iii) functional form of water retention functions (Brooks and Corey vs. van Genuchten); and (iv) type of lower boundary condition (seepage face vs. unit gradient for the lysimeter study).

Scanlon et al. (2002) suggested that models solving Richards equation (as HYDRUS-1D) were probably performing better under warm and dry climate during which matric potential gradients, besides gravity-flow, may contribute significantly to upward water fluxes. In the present study, with analogue stations from a subtropical climate class, a not too coarse soil texture and the presence of groundwater at relatively shallow depth caused matric potential driven flow to be an important factor for the water balance. Using a capacity-type model would probably overestimate drainage and groundwater recharge (Scanlon et al., 2002). Under a forest cover, van der Salm et al. (2004) similarly noted that a Darcy based model gave more accurate drainage fluxes than a capacity model, in particular under limited water availability.

For a silt loam profile, Scanlon et al. (2002) noted that using Brooks and Corey functions resulted in overestimation of evaporation and underestimation of drainage in comparison to the van Genuchten functions.

\subsection{Other factors affecting future groundwater recharge}

On the time scale considered, other factors than climate change may have an important influence on groundwater recharge. Land use change and the dependency between climate and land use are being investigated.

Climate change is likely to induce a vegetation response, which in turn could affect the water balance. Atmospheric $\mathrm{CO}_{2}$ enrichment may dampen or amplify ecosystem response. For a given species, negative feedbacks (i.e. mechanisms counteracting possible water loss increase due to higher $\mathrm{CO}_{2}$ concentrations and $\mathrm{ET}_{0}$ ) are more likely in order to promote ecosystem stability or homeostasis in ecosystem processes (Polley et al., 2011). A classic example is water savings (anti-transpiration) by plants from partial stomatal closure induced by higher $\mathrm{CO}_{2}$ concentrations, which may offset any enhancement in evaporation brought about by coincident warming (Morgan et al., 2011, having results for a semi-arid grassland). Positive feedbacks on $\mathrm{CO}_{2}$ responses are less frequent but occur most frequently through changes in plant species and functional group composition (Polley et al., 2011).

For grassland most of the time biomass response to $\mathrm{CO}_{2}$ enrichment experiments is due to water saving effects driven by stomatal closure as a response to higher $\mathrm{CO}_{2}$ (Körner, 2006). Consequently, such soil/atmospheric and vegetation responses and feedback mechanisms may also influence the net outcome in water savings, for example increases in the leaf area index may counteract potential soil-moisture savings (Morgan et al., 2011). Although a process-based 


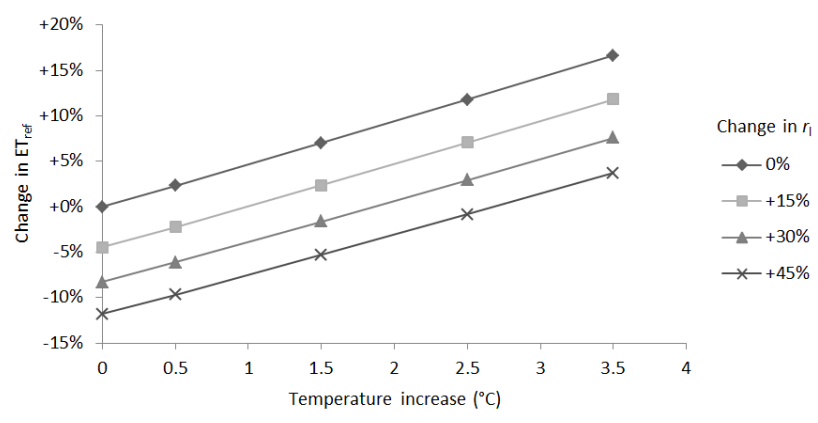

Fig. 6. Change (\%) in $\mathrm{ET}_{\text {ref }}$ calculated with the ASCE form equation for potential ET, as a function of temperature increase and increase in the bulk stomatal resistance $\left(r_{l}\right)$ as a consequence of higher $\mathrm{CO}_{2}$-induced stomatal closure. Calculations used climate data for Dessel from 1984 to 2005.

simulation of vegetation response and feedback mechanisms is beyond the scope of this paper, a sensitivity analysis of the calculated $\mathrm{ET}_{0}$ allows assessing what would be the net result between water saving effects due to higher $\mathrm{CO}_{2}$ and concurrent climate change following a similar approach as described in Morgan et al. (2011).

Climate data from 1984 to 2005 representative of Dessel was used to calculate potential ET either as a function of vegetation response (stomatal closure - bulk stomatal resistance in the American Society of Civil Engineers (ASCE) form of potential ET equation; Allen et al., 2005) or as function of a hypothetical temperature increase applied uniformly to all temperature data (radiation, humidity and wind data are kept constant). Gijon subtropical climate is on average $3.5^{\circ} \mathrm{C}$ warmer than Dessel, hence ET was calculated by considering a temperature increase from 0 up to $3.5^{\circ} \mathrm{C}$. According to Fig. 6 (modified after Morgan et al., 2011, for Dessel conditions), this results in an increase in $\mathrm{ET}_{\text {ref }}$ (potential $\mathrm{ET}$ in ASCE form) of $+4 \%$ per degree increase in temperature, or a total increase of $17 \%$ for a $3.5^{\circ} \mathrm{C}$ temperature increase. A non-linear effect of increased stomatal resistance on $\mathrm{ET}_{\text {ref }}$ is observed, e.g. $+15 \%$ resistance decreases $\mathrm{ET}_{\text {ref }}$ by $5 \%$ while $+30 \%$ reduces $\mathrm{ET}_{\text {ref }}$ by approximately $8 \%$. The latter calculations assume no change in the canopy resistance to water vapour that would result from enhanced $\mathrm{CO}_{2}$ availability. For comparison, with changing climatic variables (atmospheric pressure, radiation balance, cloud covering, temperature, humidity and wind) without vegetation response, Baguis et al. (2009) calculated an average increase of potential ET of about $+17 \%$ to $+24 \%$ for the period $2071-2100$ compared to present-day values in Belgium.

In conclusion, for grassland as the reference vegetation, the response would likely be a decrease of potential ET due to higher $\mathrm{CO}_{2}$ (plant response), but higher temperatures (climate response) could cancel this effect out, or even result in an increase of $\mathrm{ET}_{\mathrm{a}}$. In our example (Fig. 6), a combined $3.5^{\circ} \mathrm{C}$ temperature increase and $45 \%$ increase in stomatal resistance yields an increase in $\mathrm{ET}_{\text {ref }}$ of a few percent. Furthermore, the net response will also depend on annual rainfall patterns and on whether or not climatic extremes in the moisture and thermal environments occur and physiological thresholds are crossed contributing to non-linear responses (Körner, 2006; Morgan et al., 2011).

Soil development may also have an impact, because soil evolution studies in the vicinity of the Dessel site have shown that cemented podzols may develop in several thousands of years (Beerten et al., 2012). Simulations indicate (results not shown) that the average groundwater recharge is considerably affected $(-25 \%)$ if the saturated hydraulic conductivity $\left(K_{\mathrm{S}}\right)$ of the $\mathrm{Bh}$ horizon is decreased by three orders of magnitude (4.5 and $6.1 \times 10^{-9} \mathrm{~m} \mathrm{~s}^{-1}$ for Zcg and Zeg soil profiles, respectively), an outcome that can be related to the average precipitation of the Dessel site, about $900 \mathrm{~mm} \mathrm{yr}^{-1}$ or $\sim 3 \times 10^{-8} \mathrm{~m} \mathrm{~s}^{-1}$. This suggests that podzolisation may need to be considered together with other long-term changes (climate, land cover, vegetation). Recent landscape and soil evolution studies in the vicinity of the site have shown that cemented podzols may develop in several thousands of years with $K_{\mathrm{S}}$ values as low as $\sim 10^{-7} \mathrm{~m} \mathrm{~s}^{-1}$ (Beerten et al., 2012), which is almost three orders of magnitudes lower than the parent material. A $K_{\mathrm{S}}$ of $\sim 10^{-9} \mathrm{~m} \mathrm{~s}^{-1}$ is about two orders of magnitude lower that the absolute value presently observed in podzol soils in northwestern Europe. However, these soils are mostly buried or truncated soils (i.e. soil development could not continue) while unburied podzols could further develop in the next few thousands of years.

\section{Conclusions}

Groundwater recharge response to transition to a warmer, subtropical climate was studied using HYDRUS-1D and the approach of climatic analogue stations. Although no optimal choice of analogue stations may exist due to different weather circulation systems, this approach allows including observed variations of all meteorological parameters in a transparent and straightforward way.

The results showed a decrease of groundwater recharge in the vicinity of the Dessel disposal site (typical podzol with a grass cover) for all analogue stations except Gijon. Based on projected temperature and precipitation increases the Gijon station is considered a good representative analogue for Dessel for the next $10000 \mathrm{yr}$. For that station, groundwater recharge increases slightly with $+3 \%$. Other analogue stations are considered as bounding cases accounting for uncertainty about climate time evolution.

Although no colder climate is foreseen in the next $10000 \mathrm{yr}$, the approach was also tested with analogue stations for a colder climate state. Groundwater recharge simulated for the representative analogue Sisimiut showed a decrease by $85 \%$. 
Table A1. Annual temperature and precipitation of a sample of European stations representative of climate variability within the DO class, with the same selection criteria as presented in Sect. 2.2 (sources: IRM-KMI, www.meteo.be; KNMI, www.knmi.nl; Meteofrance, http://climat.meteofrance.com; Met Office, www.metoffice.gov.uk; Met Éireann, www.met.ie).

\begin{tabular}{|c|c|c|c|c|c|c|c|}
\hline Station & Country & $\begin{array}{l}\text { Altitude } \\
\text { (ma.s.1.) }\end{array}$ & $\begin{array}{l}\text { Latitude } \\
\qquad\left({ }^{\circ} \mathrm{N}\right)\end{array}$ & Years & $\begin{array}{r}\text { Annual mean } \\
\mathrm{T}\left({ }^{\circ} \mathrm{C}\right)\end{array}$ & $\begin{array}{r}\text { Number of } \\
\text { months }>10^{\circ} \mathrm{C}\end{array}$ & $P\left(\mathrm{~mm} \mathrm{yr}^{-1}\right)$ \\
\hline Dessel & Belgium & 20 & 51.2 & 1984-2009 & 10.3 & 6 & 899 \\
\hline Bordeaux & France & 47 & 44.8 & $1971-2000$ & 13.3 & 7 & 984 \\
\hline Rennes & France & 36 & 48.1 & $1971-2000$ & 11.8 & 6 & 677 \\
\hline Lille-Lesquin & France & 47 & 50.6 & $1971-2000$ & 10.4 & 6 & 723 \\
\hline Bude & United Kingdom & 15 & 50.8 & $1971-2000$ & 10.7 & 6 & 923 \\
\hline Coxyde & Belgium & 2 & 51.1 & 1961-1990 & 9.4 & 6 & 687 \\
\hline Rotterdam & The Netherlands & -5 & 51.9 & 1971-2000 & 10.0 & 6 & 816 \\
\hline De Bilt & The Netherlands & 2 & 52.1 & $1971-2000$ & 9.8 & 6 & 793 \\
\hline Shannon & Ireland & 20 & 52.7 & 1961-1990 & 10.1 & 6 & 927 \\
\hline Leeuwarden & The Netherlands & 0 & 53.2 & 1971-2000 & 9.2 & 6 & 767 \\
\hline Manchester & United Kingdom & 69 & 53.5 & 1971-2000 & 9.8 & 6 & 807 \\
\hline Paisley & United Kingdom & 32 & 55.8 & $1971-2000$ & 9.3 & 5 & 1205 \\
\hline
\end{tabular}

Given the limitations of the approach - including limitations inherent to the use of climate analogues, the soil water balance model being uncoupled from a groundwater flow model, etc. - and being a purely modelling study without validation data, the results regarding future groundwater recharge and depth need to be interpreted as relative rather than absolute outcomes.

A deep drainage bottom boundary condition was used but may not be optimal for the problem examined. Further developments will focus on coupling the unsaturated zone model with a local hydrogeological model (Seo et al., 2007; Gedeon and Mallants, 2010). For colder climate states, it is also necessary to investigate the effect of freeze-thaw cycles and snow evaporation on groundwater recharge.

\section{Appendix A}

\section{Climate variability in DO class}

See Table A1.

\section{Appendix B}

\section{Canopy water balance model}

In this model described by Jacques et al. (2011), the canopy water balance per unit area, for day "d", is written as

$\Delta S=P_{\mathrm{d}}-\left(E_{\mathrm{i}, \mathrm{d}}+\operatorname{Tr}_{\mathrm{d}}\right)$

where $\Delta S\left[\mathrm{~mm} \mathrm{day}^{-1}\right]$ is the variation of canopy storage over one day, $P\left[\mathrm{~mm} \mathrm{day}^{-1}\right]$ is precipitation, $E_{\mathrm{i}}\left[\mathrm{mm} \mathrm{day}^{-1}\right]$ is evaporation of intercepted water and $\operatorname{Tr}_{\mathrm{d}}\left[\mathrm{mmday}^{-1}\right]$ is throughfall. The maximum amount of water left on the canopy at start of the day is defined by the interception capacity, $w_{\mathrm{c}}[\mathrm{mm}]$. On a daily basis (start of the day), the throughfall is calculated as

$\operatorname{Tr}_{\mathrm{d}}= \begin{cases}S_{\mathrm{d}-1}+P_{\mathrm{d}}-w_{\mathrm{c}} & \text { if } S_{\mathrm{d}-1}+P_{\mathrm{d}}>w_{\mathrm{c}} \\ 0 & \text { if } S_{\mathrm{d}-1}+P_{\mathrm{d}} \leq w_{\mathrm{c}}\end{cases}$

and an intermediate value of canopy storage, $S_{\mathrm{d}, \mathrm{i}}[\mathrm{mm}]$ is calculated as

$S_{\mathrm{d}, \mathrm{i}}= \begin{cases}w_{\mathrm{c}} & \text { if } S_{\mathrm{d}-1}+P_{\mathrm{d}}>w_{\mathrm{c}} \\ S_{\mathrm{d}-1}+P_{d} & \text { if } S_{d-1}+P_{\mathrm{d}} \leq w_{\mathrm{c}} .\end{cases}$

Then, the storage is corrected for evaporation of water from the leaf surface. The latter is obtained by splitting the daily potential crop evapotranspiration $\mathrm{ET}_{\mathrm{c}, \mathrm{d}}\left[\mathrm{mm} \mathrm{day}^{-1}\right]$ (calculated using Penman-Monteith equation) into daily potential soil evaporation $E_{\mathrm{p}, \mathrm{d}}\left[\mathrm{mm} \mathrm{day}^{-1}\right.$ ], daily potential transpiration $T_{\mathrm{p}, \mathrm{d}}\left[\mathrm{mm} \mathrm{day}^{-1}\right]$ and $E_{\mathrm{i}, \mathrm{d}}$ :

$E_{\mathrm{i}, \mathrm{d}}+T_{\mathrm{p}, \mathrm{d}}=\mathrm{ET}_{\mathrm{c}, \mathrm{d}}-E_{\mathrm{p}, \mathrm{d}}$.

Assuming that the net radiation inside the canopy decreases according to an exponential function and that soil heat flux can be neglected, $E_{\mathrm{p}, \mathrm{d}}$ is calculated as (Goudriaan, 1977; Belmans et al., 1983; Kroes et al., 2008)

$E_{\mathrm{p}, \mathrm{d}}=\mathrm{ET}_{\mathrm{c}, \mathrm{d}} \exp \left(-k \mathrm{LAI}_{\mathrm{d}}\right)$

where $k[-]$ is the light extinction coefficient and LAI [-] is the leaf area index. $E_{\mathrm{i}, \mathrm{d}}$ depends on the canopy storage. If $S_{\mathrm{d}, \mathrm{i}}>E T_{\mathrm{c}, \mathrm{d}}-E_{\mathrm{p}, \mathrm{d}}$, the following applies:

$T_{\mathrm{p}, \mathrm{d}}=0$

$S_{\mathrm{d}}=S_{\mathrm{d}, \mathrm{i}}-\left(\mathrm{ET}_{\mathrm{c}, \mathrm{d}}+E_{\mathrm{p}, \mathrm{d}}\right)$.

In case $S_{\mathrm{d}, \mathrm{i}} \leq \mathrm{ET}_{\mathrm{c}, \mathrm{d}}-E_{\mathrm{p}, \mathrm{d}}$, the following applies:

$T_{\mathrm{p}, \mathrm{d}}=\left(\mathrm{ET}_{\mathrm{c}, \mathrm{d}}+E_{\mathrm{p}, \mathrm{d}}\right)-S_{\mathrm{d}, \mathrm{i}}$

$S_{\mathrm{d}}=0$. 
$S_{\mathrm{d}}$ is then used as a starting value for storage to calculate the boundary water balance terms for the next day.

Concerning vegetation parameters, the interception capacity for grass was fixed at $0.55 \mathrm{~mm}$ (giving on average $15 \%$ of precipitation intercepted), a constant LAI of 2 was used and the light extinction coefficient was 0.5 (Jacques et al., 2011).

Acknowledgements. This work has been performed as part of the project on disposal of category A waste - short-lived low and intermediate level waste (LILW-SL) - that is carried out by ONDRAF/NIRAS, the Belgian Agency for Radioactive Waste and enriched Fissile Materials.

The authors wish also to acknowledge the Royal Meteorological Institute (Belgium), the Spanish Meteorology Agency (Agencia Estatal de Meteorologia, Ministerio de Medio Ambiente y Medio Rural y Marino) and the Danish Meteorological Institute (Danmarks Meteorologiske Institut) for providing meteorological data.

Edited by: R. P. Bartholomeus

\section{References}

Allen, R. G., Pereira, L. S., Raes, D., and Smith, M.: Crop evapotranspiration: Guidelines for computing crop water requirements, Irrigation and Drainage Paper, No. 56, Tech. rep., 1998.

Allen, R. G., Walter, I., Elliott, R., Howell, T., Itenfisu, D., Jensen, M., and Snyder, R.: The ASCE standardized reference evapotranspiration equation, Am. Soc. Civil Eng., Reston, VA, 2005.

Baguis, P., Ntegeka, V., Willems, P., and Roulin, E.: Extension of CCI-HYDR climate change scenarios for INBO, Instituut voor Natuur- en Bosonderzoek (INBO) \& Belgian Science Policy SSD Research Programme, K.U.Leuven - Hydraulics Section \& Royal Meteorological Institute of Belgium, 31 pp., Tech. rep., 2009.

Batelaan, O. and De Smedt, F.: GIS-based recharge estimation by coupling surface-subsurface water balances, J. Hydrol., 337, 337-355, doi:10.1016/j.jhydrol.2007.02.001, 2007.

Bechtel SAIC Company, L.: Future Climate Analysis, Tech. rep., Bechtel SAIC Company, LLC, 2004.

Beerten, K., Wemaere, I., Gedeon, M., Labat, S., Rogiers, B., Mallants, D., and Salah, S.: Geological, hydrogeological and hydrological data for the Dessel disposal site. Report NIROND-TR 2009-05E, SCK-CEN, Mol, Belgium, Tech. rep., 2010.

Beerten, K., Deforce, K., and Mallants, D.: Landscape evolution and soil hydrological changes at the decadal, centennial and millennial scale: a case study from the Campine area, northern Belgium, Catena, 95, 73-84, 2012.

Belmans, C., Wesseling, J. G., and Feddes, R. A.: Simulation of the water balance of a cropped soil: SWATRE, J. Hydrol., 63, 271286, 1983.

BIOCLIM: Modelling Sequential Biosphere Systems under Climate change for Radioactive Waste Disposal, Final Report ECcontract FIKW-CT-2000-00024, Tech. rep., ANDRA, 2003.

Burgess, P. E., Palutikof, J. P., and Goodess, C. M.: Estimating Past and Future Climate and Sea Level: Climate Research in Support of the Next Drigg Safety Case: Phase I and Phase II, Tech. rep., RP/0103169/R \& T/00129, 20 December 2002, Level III report DTP/129 quoted in the Drigg Post-Closure Safety Case: Overview Report, BNFL, 2002.

Fowler, H. J., Blenkinsop, S., and Tebaldi, C.: Linking climate change modelling to impacts studies: recent advances in downscaling techniques for hydrological modelling, Int. J. Climatol., 27, 1547-1578, 2007.

Gedeon, M. and Mallants, D.: Hydrogeological model of the Dessel site, Report NIROND-TR 2008-15E V2, SCK-CEN, Mol, Belgium, Tech. rep., 2010.

Goderniaux, P., Brouyère, S., Fowler, H. J., Blenkinsop, S., Therrien, R., Orban, P., and Dassargues, A.: Large scale surfacesubsurface hydrological model to assess climate change impacts on groundwater reserves, J. Hydrol., 373, 122-138, doi:10.1016/j.jhydrol.2009.04.017, 2009.

Goudriaan, J.: Crop micrometeorology: a simulation study, Simulation Monographs, Wageningen, 1977.

Hardy, L., Mallants, D., and Volckaert, G.: Hydrogeological model for the safety evaluation: groundwater flow and transport calculations for the nuclear zone Mol-Dessel, R-3550, Tech. rep., Waste \& Disposal Department, SCK-CEN, 2001.

Holman, I. P., Tascone, D., and Hess, T. M.: A comparison of stochastic and deterministic downscaling methods for modelling potential groundwater recharge under climate change in East Anglia, UK: implications for groundwater resource management, Hydrogeol. J., 17, 1629-1641, 2009.

Hopmans, J. W. and Stricker, J. N. M.: Stochastic analysis of soil water regime in a watershed, J. Hydrol., 105, 57-84, 1989.

IPCC: Climate Change 2007: The Physical Science Basis, in: Contribution of Working Group I to the Fourth Assessment Report of the Intergovernmental Panel on Climate Change, edited by: Solomon, S., Qin, D., Manning, M., Chen, Z., Marquis, M., Averyt, K. B., Tignor, M., and Miller, H. L., p. 996, Cambridge University Press, Cambridge, United Kingdom New York, USA, 2007.

Iwata, Y., Hayashi, M., and Hirota, T.: Comparison of Snowmelt Infiltration under Different Soil-Freezing Conditions Influenced by Snow Cover, Vadose Zone J., 7, 79-86, 2008.

Jacques, D., Mallants, D., and Leterme, B.: Modelling potential and actual evapotranspiration and drainage at the nuclear zone MolDessel, Report NIROND-TR 2008-25E V2, SCK-CEN, Mol, Belgium, Tech. rep., 2011.

Körner, C.: Plant $\mathrm{CO}_{2}$ responses: an issue of definition, time and resource supply, New Phytol., 172, 393-411, 2006.

Kroes, J. G., van Dam, J. C., Groenendijk, P., Hendriks, R. F. A., and Jacobs, C. M. J.: SWAP version 3.2. Theory description and user manual, Tech. rep., Alterra, Alterra Report 1649, 2008.

Leterme, B., Jacques, D., Mallants, D., Hooker, P., De Craen, M., and Van den Hoof, C.: Long-term climate change and effects on disposal facility, geosphere, and biosphere, Report NIROND-TR 2009-07E, SCK-EN, Mol, Belgium, Tech. rep., 2012.

Maxwell, R. M. and Kollet, S. J.: Interdependence of groundwater dynamics and land-energy feedbacks under climate change, Nat. Geosci., 1, 665-669, 2008.

Mertens, J., Raes, D., and Feyen, J.: Incorporating rainfall intensity into daily rainfall records for simulating runoff and infiltration into soil profiles, Hydrol. Process., 16, 731-739, 2002.

Morgan, J. A., LeCain, D. R., Pendall, E., Blumenthal, D. M., Kimball, B. A., Carrillo, Y., Williams, D. G., Heisler-White, J., Dijkstra, F. A., and West, M.: C4 grasses prosper as carbon dioxide 
eliminates desiccation in warmed semi-arid grassland, Nature, 476, 202-205, doi:10.1038/nature10274, 2011.

Palutikof, J. P. and Goodess, C. M.: Analogue scenarios of future climates of the U.K., in: Future Climate Change and Radioactive Waste Disposal, Proceedings of the International Workshop, University of East Anglia, 1-3 November 1989, edited by: Goodess, C. M. and Palutikof, J. P., 225-244, Nirex Report NSS/R257, 1991.

Peck, A. J.: Note on the role of a shallow aquifer in dryland salinity, Soil Res., 16, 237-240, 1978.

Polley, H. W., Morgan, J. A., and Fay, P. A.: Application of a conceptual framework to interpret variability in rangeland responses to atmospheric $\mathrm{CO}_{2}$ enrichment, J. Agr. Sci., 149, 1-14, 2011.

Scanlon, B. R., Christman, M., Reedy, R. C., Porro, I., Simunek, J., and Flerchinger, G. N.: Intercode comparisons for simulating water balance of surficial sediments in semiarid regions, Water Resour. Res., 38, 1323, doi:10.1029/2001WR001233, 2002.

Schaap, M. G., Leij, F. J., and van Genuchten, M. T.: Bootstrap neural network approach to predict soil hydraulic parameters, in: Proceedings of the international workshop, Characterization and measurement of the hydraulic properties of unsaturated porous media, Part 2, 1237-1250, University of California, Riverside, USA, 1999.

Seo, H. S., Šimunek, J., and Poeter, E. P.: Documentation of the HYDRUS Package for MODFLOW-2000, the US Geological Survey Modular Ground-Water Model, GWMI 2007-01, Int. Ground Water Modeling Center, Colorado School of Mines, Golden, CO, 2007.

Seuntjens, P., Mallants, D., Toride, N., Cornelis, C., and Geuzens, P.: Grid lysimeter study of steady state chloride transport in two Spodosol types using TDR and wick samplers, J. Contam. Hydrol., 51, 13-39, 2001.

Šimủnek, J., Šejna, M., and van Genuchten, M. T.: HYDRUS-1D, version 4.14, code for simulating the one-dimensional movement of water, heat, and multiple solutes in variably saturated porous media, Tech. rep., University of California Riverside, 2005.

Stoll, S., Hendricks Franssen, H. J., Barthel, R., and Kinzelbach, W.: What can we learn from long-term groundwater data to improve climate change impact studies?, Hydrol. Earth Syst. Sci., 15, 3861-3875, doi:10.5194/hess-15-3861-2011, 2011.
Trewartha, G. T., Robinson, A. H., and Hammond, E. H.: Fundamentals of Physical Geography, McGraw-Hill Co, New York, 1968.

van der Salm, C., Reinds, G. J., and de Vries, W.: Assessment of the Water Balance of European Forests: A Model Study, Water Air Soil Poll., 4, 175-190, 2004.

Van Geet, M., De Craen, M., Beerten, K., Leterme, B., Mallants, D., Wouters, L., Cool, W., and Brassines, S.: Climate evolution in the long-term safety assessment of surface and geological disposal facilities for radioactive waste in Belgium, Geol. Belg., 15, 8$15,2012$.

van Genuchten, M. T.: A closed-form equation for predicting the hydraulic conductivity of unsaturated soils, Soil Sci. Soc. Am J., 44, 892-898, 1980.

Van Orshoven, J., Maes, J., Vereecken, H., Feyen, J., and Dudal, R.: A structured database of Belgian soil profile data, Pedologie, XXXVIII, 191-206, 1988.

van Roosmalen, L., Sonnenborg, T. O., and Jensen, K. H.: Impact of climate and land use change on the hydrology of a largescale agricultural catchment, Water Resour. Res., 45, W00A15, doi:10.1029/2007WR006760, 2009.

Vandenberghe, J.: Paleoenvironment and stratigraphy during the Last Glacial in the Belgian-Dutch border region, Quaternary Res., 24, 23-38, 1985.

Vandenberghe, J.: Changing fluvial processes under changing periglacial conditions, Z. Geomorphol., Supplement Band, 88, 17-28, 1993.

Wemaere, I., Hardy, L., Van Keer, I., Marivoet, J., Labat, S., and Sillen, X.: A Palaeohydrogeological study of the Mol site (PHYMOL project), Tech. rep., 1999.

Wilkinson, W. B. and Cooper, D. M.: The response of idealized aquifer/river systems to climate change, Hydrolog. Sci., 38, 379$390,1993$. 